International Journal of Engineering \& Technology, 7(3.2)(2018) 631-635
International Journal of Engineering \& Technology
SPC
Website: www.sciencepubco.com/index.php/IJET
Research paper

\title{
World Experience of Using Water Reservoirs in the Structure of Basic Horizontal Planes of an Architectural Object
}

\author{
Yana Kuznietsova ${ }^{1} *$ \\ ${ }^{1}$ Poltava National Technical Yuri Kondratyuk University, Ukraine \\ *Corresponding Author E-Mail: Yana.Arch.De@Gmail.Com
}

\begin{abstract}
The aim of the article is to popularize the ecological approach in building both in Ukraine and states of the former Soviet Union. Previously the author studied issues of using water as a natural component on local and object levels in the structure of basic horizontal planes as connecting and outer spaces. This article deals with basic horizontal planes of buildings. The author analyzed architectural objects containing water as a natural component in their structure, and considered quality features of this approach. Firstly, these features influence psychology and physiology of a person, aesthetic perception of architectural objects and secondly, they have ecological aspects such as solving problems of heat isolation, precipitation cleansing, reducing the level of air pollution, atmospheric dispersion, etc. The article is based on the world experience of using water reservoirs in the structure of an architectural object. The author determined methods of water use and its influence on architectural form making. Watermorphic approach in architecture is defined as self-sufficient.
\end{abstract}

Keywords: architectural form making; ecology; natural component; water; watermorphic architecture.

\section{Introduction}

In the last ten years special architectural approaches such as green architecture, earthwork, ecological and energy-efficient architecture have become widespread. The author pays attention to the use of natural components such as water, soil, vegetation in the structure of architectural objects and to their influence on form making of buildings. The above-mentioned building materials are becoming more and more popular due to a number of their positive features in line with the ecological approach in architecture. Intense interest to this approach can be explained by increasing ecological awareness of people who recognize their role in the biological, physical and chemical world and have certain mental level of reflecting natural and artificial environment [1]. Our society clearly understands their connection with nature and taking into account its modern state is eager to renew harmony and unity which existed in the past.

Environmental problems in the modern world are global. However, the efforts to solve them are not in vain. Different areas of science have a number of ideas and implemented projects. Solving environmental problems with the help of architectural means is not an exception. The main architectural tendency is the development within the framework of an ecological paradigm [2].

The importance of nature in people's lives was first emphasized by the ancient Greek philosopher, scientist and logician Aristotle and the philosopher and sophist Plato. Eventually the scientific world began to study the relationship between nature and architecture through biological theories; the following scientists made the most significant contribution: Albert Leon Batista, August Wilhelm von Schlegel, Friedrich Wilhelm Joseph von Schelling, Aloys Hirt, etc. City-planning theories of ideal cities belonging to Claude Nicolas Ledoux, Charles Fourier, Ebenezer Howard and
Frank Lloyd Wright made the following step. We have to point out that the notion "society-nature-architecture" has existed for over a thousand years although active implementation of natural landscape components into architectural objects has been observed since the 1970s. Due to urban development architectural object start to force nature out of cities; in spite of government regulations green space in cities has decreased over the years. The rise of concrete jungle has brought new ecological, aesthetic, psychological and physiological problems for people. There are no free areas in modern cities, therefore nature returns to them in a different way, through arranging green spaces on horizontal and vertical areas of buildings, partial or complete immersion of buildings into soil or water.

\section{Review of Research and Publications}

To research the topic the author used empirical and theoretical methods. The main study phase was to collect and process basic information on the use of natural components in architectural form making. The main information is systemized according to the following criteria: derivation of the idea; its generation and development; finding scientists who study different aspects of the topic; search for uncovered issues, problem statement and its further analysis; finding architects whose works promote to some extent the development of architecture using natural landscape components.

Theoretically the research is based on the cooperation of architecture and nature, this issue is studied in the works of the following authors: John Ruskin, E. Howard, L. Sullivan, F.L. Wright, R. Steiner, P. Portoghesi, Ch. Jencks, P. Hans, A. K. Burov, Y.S. Lebedev, A.I. Lazariev, M. Sorkin, B. Zevi. 
Among theoretical works investigating compositional approaches in architecture and architectural form making we should pay attention to: Y.S. Lebedev, V.I. Rabynovych, who studied and defined building principles in bionic architecture, S. Pronin, who investigates the use of combination principles in design, N.G. Shapoval, who studies the basics of architectural form making, I. Dobritsina, who analyzes the idea of nonlinearity in architecture, O.G. Rappaport, who looks at the historical and theoretical background of form making. V.A. Nefiedova thinks that architecture is closely connected with landscape and considers the use of natural components in the structure of an object; A. Y. Zaslavska studied the origins of organic architecture and is now involved into the issue of organic approach to form making in modern architecture [3]; Y.S. Yankovska studies the relationship between image and morphology of an architectural object; O.M. Karasyova looks into the principles and methods of architectural organization of hotels situated in the natural habitat. D.A. Chyzhmak studied the issue of form making of ecological high rise buildings [4]. Y.S. Gordienko investigates the principles of nature integrated architecture [5] The following architects and architectural groups use natural components in form making of their buildings: Tadao Ando, F. Hundertwasser, P. Vetsch, Patrick Blanc, Emilio Ambasz, Ken Yeang, Kengo Kuma, Vincent Callebaut, Nicholas Grimshaw; companies: Fytogreen, Green Wall, Mass Studies, Aedas, Green Roof Consultancy Ltd, GreenOverGrey, Ian Simpson Architects, Skylab Architecture, SITE, Rafaf Architecture and Design, MVRDV, Deep Ocean Technology, Us Submarines, etc.

The above-mentioned analysis shows that nature and architecture have been together since ancient times. Quite a few scientists have studied this issue in their works. The use of natural landscape components is becoming a widespread topic but the use of water has not been sufficiently studied. In the previous research the author examined the influence of water on architectural form making of an object. This article deals with analyzing the use of water reservoirs in the structure of basic horizontal planes of an object.

\section{Statement of the Main Material of Research and Publications}

Return to the use of soil and vegetation in architecture has become one of modern tendencies. This issue is well studied unlike the use of water as a natural component in architectural objects. This component has a number of features, such as flexibility, glassiness, colour spectrum, dynamism. Its ecological characteristics are reducing air pollution, cleaning the air from dust and gases, diffusion of toxic air pollutants, high heat conduction and heat storage capacity, which is twice higher than the same capacity of soil, etc. It is a historical tradition to place houses near water. Nowadays this tradition continues in constructing buildings under and on water, making various objects in water columns, etc. The use of water on vertical elements is becoming increasingly popular; at first the author suggests the following methods:

- water curtain,

- mimicry

- aquarium [6].

Water is the only element that can be in different physical forms solid, i.e. ice; liquid, i.e. water; gas, i.e. water steam. These characteristic features of the natural component greatly influence modern architectural form making. We can state that watermorphic architecture is a self-sufficient architectural approach.

In his book «Architecture: Form, Space and Order» Francis DK Ching introduces the notion of basic horizontal and vertical planes which form an architectural object: the roof, the floor, the walls [7]. We will look at the integration of water as a natural component into the structure of basic horizontal planes. Creation of gardens with water elements on roofs or complete replacement of a roof with water is not a new technique. It is characterized with the use of artificial water reservoirs, swimming pools on roofs, recessed balconies, etc. This technique can influence architectural form making in different ways depending on the place where the person is and on how much of a horizontal plane they can see.

\section{Using Water as a Natural Component in Interspaces}

The author has conducted analysis of more than 100 examples and come to the conclusion that water reservoirs are most often used in interspaces, such as balconies, recessed balconies and terraces of hotels, multistoried buildings, and luxury residential houses. These water reservoirs are not big, which gives an opportunity to make construction more cost effective and to increase service charges due to improved comfort of an architectural object. Aesthetically such interspaces have an advantage over standard design, improve quality characteristics of staying in such environment, especially in countries with high outdoor temperatures. Configuration of water elements is limitless. In India architect James Law proposed the project of Aquaria Grande hotel, where on each of the thirty seven floors, absolutely all rooms with the balconies have swimming pools. This idea will be interesting for all guests and third-party of observers. The balcony space with each floor shifts to a certain distance and with the smooth form of the pool, creates a wave effect that passes through the entire facade. The technique which is used in this project gives some dynamics in it design solution (e.g. Figure 1 a). While constructing such objects, considerable attention is paid to building systems which can provide for the safety of an object taking into account the amount of water used. Designing a multistoried residential house on the $\mathrm{Ba}-$ hamas architectural group BIG, in collaboration with HKS Architects and Michael Diggiss Architects suggested placing a vertical composition of water reservoirs on the facade of a building in the form of a cell system made of concrete imitating a little flattened combs (e.g. Figure 1 b). Varieties of water using in interspaces levels are not limited general pool. For example the Hacienda $\mathrm{Na}$ Xamena hotel, which is located on the island of Ibiza. The structure is located on a rock, 180 meters above sea level. On the best rooms terraces are cascades of thermal pools and jacuzzi.
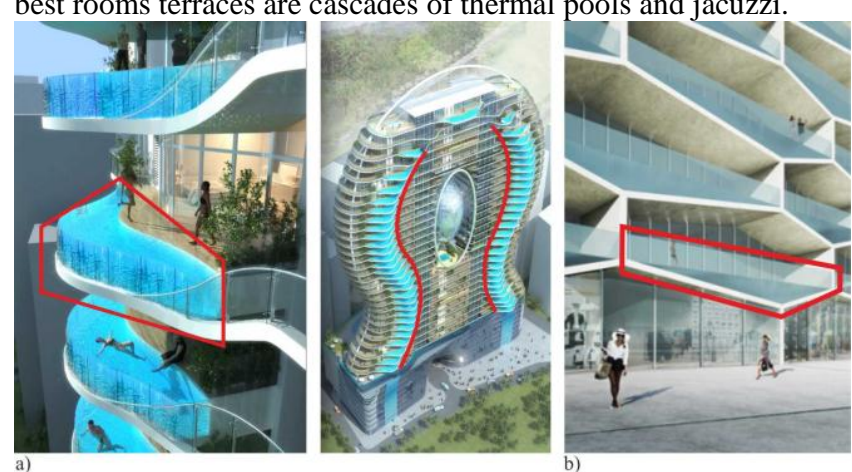

Fig. 1: Placement of water reservoirs in interspaces; a) Project Aquaria Grande, architect James Law, Source: [9]; b) Multistoried residential house, architectural groups BIG, HKS and MDA. Source: [10]

\section{Integration of Water Reservoirs Into Basic Horizontal Planes of an Architectural Ob- ject}

Water as an integral part of a basic horizontal plane of an object can be used in various ways. Depending on the type of a building there are different priorities of using this natural component. It is relevant to use water reservoirs in shopping centres, office and civil buildings. Also architects frequently create artificial gardens which usually combine three components: water, soil and vegetation. Such roofs are called intensive green roofs; they should be looked after by specialists and give an opportunity to place a large number of visitors as well. Design of artificial water reservoirs has both aesthetic and practical advantages. These reservoirs can be exploited to collect and purify water which is further used for watering or sanitary purposes. It is important to state that such 
projects always involve the notion of a water effective landscape, one of the criteria in the international system of energy standards LEED [11].

Swimming pools are used in hotels, skyscrapers, multistoried residential houses and individual building. Taking into consideration the fact that attending sports complexes or visiting natural water reservoirs takes time, it is popular to place a swimming pool on the roof of a building. Such technique is quite widespread in hot climate countries. In hotel business placement of a swimming pool on the roof increases demand, especially in resorts where hotels are not situated in close proximity to the sea or ocean and temperatures are extremely high, for instance, UAE. The author determines the following techniques of placing a swimming pool on the roof: an aquarium, a swimming pool "bridge", a second light swimming pool.

An "aquarium" is a swimming pool made of glass, therefore we can see views of a city or nature through its floor and in turn a person who is in such a pool can be seen by people who are on lower floors or even pedestrians, if the building is not very high (depending on where the main amount of water is placed). Such swimming pools have various geometrical shapes and, as a rule, a skew corbel outside the facade. They are a kind of extreme rest, because of transparency of the construction and the great height it is hard for a person to believe in the safety of such pools. Examples of the technique are as follows: the swimming pool Sky Pool in the skyscraper Market Square Tower, USA (this object is three metres out of the facade and is situated on the forty second floor (e.g. Figure 2 a); Glass Bottom Pool in Hotel Joule, China; hotel «The Edge Villas», Bali (the swimming pool is built on the edge of a cliff over the Indian Ocean on the height of one hundred fifty two metres); the swimming pool in InterContinental Festival City Hotel, Dubai; Adelphi hotel in Melbourne, Australia, etc.

The next technique "a second light swimming pool" has a significant influence on the form making of both outside and inside spaces. As a result of using transparent constructions which are situated over living and additional spaces and partly outside the object space, sunlight coming through the water is deflected and throws shades on walls and the floor of a building creating a particular interior. Portuguese company Guedes Cruz Architects presented an implemented project Wall House in Lisbon. Except special planning solutions and concentration of attention on a mass of glass walls, authors suggest placement of two swimming pools. The first one is a standard pool situated on the ground level, its territory is meant as a place of rest for owners; it is very big and has several functional zones for receiving guests. The second pool is situated above the first one; its lower constructive part is a light transparent floor of the lower terrace. A certain division of spaces is created due to the glass floor of the swimming pool, however, lower levels receive enough sunlight and visible constructive systems partly shade the space creating comfortable conditions. The second light swimming pool also becomes the ceiling for certain rooms in the house creating unbelievable interior. (e.g. Figure $2 \mathrm{~b}$ ). A similar object Shaw House is presented by the company Patkau Architects. The building site was narrow and there was no opportunity to design natural side light in all rooms. The authors make a decision to create a construction of transparent swimming pools, which gave an opportunity to both lighten the premises and to create additional places for rest. It is necessary to point out that the interior of such buildings is usually minimalistic as far as the walls are concerned as the play of light brings its own solutions which change during the day and depending on the movement of water. The above-mentioned technique is used both in individual building and in construction of civil buildings of different purposes.

The main idea of the technique swimming pool "bridge" is to visually connect two parts of a building with the help of an additional structure, i.e. a swimming pool. This technique has several variations; "connecting bridges" can have transparent horizontal base (making them close to the "aquarium" technique) and can be made of a strong solid material which makes the structure safe both on construction and psychological levels.
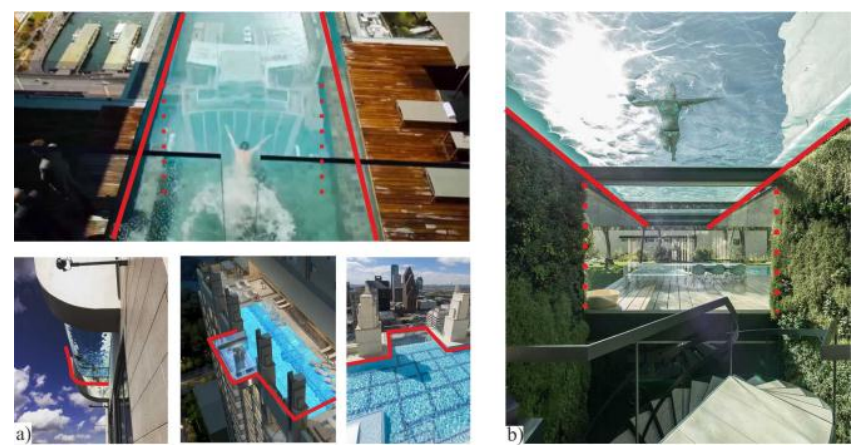

Fig. 2: Placement of swimming pools on a horizontal roof - «aquarium». a) Design of a residential house, London. Source: [12]; b) Wall House, Portugal , Guedes Cruz Architects. Source: [13]

Residential complex Sky Habitat in Singapore designed by the architect Moshe Safdie is an example of the above-mentioned technique. Two identical objects with terraced roofs are connected with three passages. The author himself calls them "air bridges". The idea is to create communication spaces for residents of the building. In conditions of building in sites with high population density, lack of greenery and recreation places, 38-storey residential complex is a perfect example of solving these problems. Two "bridges" are covered with green oasis gardens and the third one connects the objects with the help of a 40-metre swimming pool. Although the swimming pool is situated on the height of 100 metres, there is no feeling of discomfort as the swimming pool does not have a light transparent floor. It is interesting to point out that Moshe Safdie is very good at using terms, in English «habitat» means natural environment and that is how the architect saw his object. «Embassy Gardens» created by design and engineering company Arup follows a similar technique. A 30-metre swimming pool is situated on the tenth floor and joins together two blocks of residential houses. This connecting element has a completely light transparent floor and walls. In the above-mentioned project we do not see any distinct ecological aspects, this water reservoir represents a certain conceptual contrast in a residential complex. Architects call swimming pools of this type "sky pools" as due to light deflection and to significant height of an object it is perceived as a part of the sky (e.g. Figure 3 a).

Integration of a water component into the structure of a basic horizontal plane gives practically $100 \%$ filling. Such a roof will have large reservoirs for water with a few pedestrian paths and entrances or can be situated completely under the water without an opportunity to be attended by visitors (except the service personnel). Now we will look at the technique of a "water mirror" which includes large areas of artificial water reservoirs. Oasis 21 or Spaceship Aqua situated in Nagoya, Japan is a public territory containing a bus station, a café and a chain of shops (e.g. Figure 4 b). The area is covered with a 106 roof containing a water reservoir whose base is partially made of glass, a light transparent material. Depending on time of the day and season the roof of this complex is lightened with different colours, which in combination with the water reservoir has a significant influence on the area under the roof creating unforgettable images which constantly change. Another interpretation of the technique is a residential house in Turkey. Three parts of the building are situated not far from each other and are covered with water roofs which are reservoirs for collecting rain water. The roof is made as a cascade, which gives water an opportunity to circulate and to create a certain system of natural cooling. This way of air conditioning is front and centre in the hot climate of the country (e.g. Figure 4 a).

An addition to the previously described technique is a "water mirror + entrance". This technique is not very popular and is about creating the main entrance in a weird way by making an opening in the basic horizontal plane of the roof covered with the water component. Such interpretation of an entrance has some drawbacks 

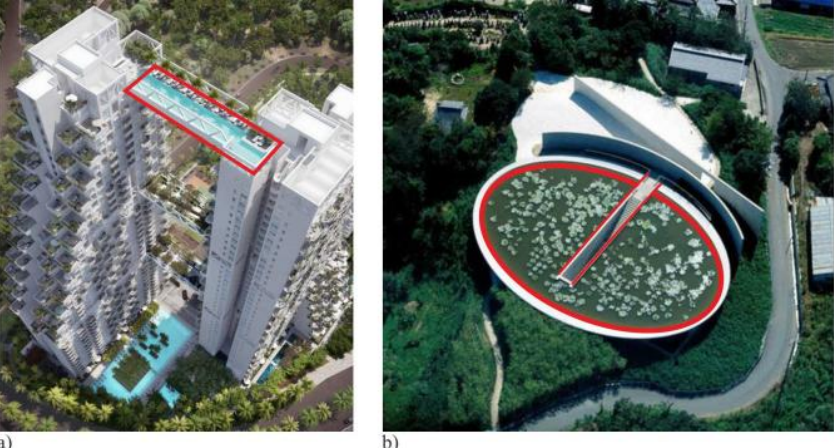

Fig. 3 a): Placement of water reservoirs on a horizontal plane - swimming pool "bridge". Sky Habitat project, Singapore, architect Moshe Safdie. Source: [14]; b) "water mirror + entrance" technique. Water Temple Japan, architect Tadao Ando. Source: [15]

but in general is more idealistic. Tadao Ando represents the above-mentioned situation in his project the Water Temple. He uses this idea to emphasize the transition from an ordinary daily life to a special atmosphere of a Buddhist temple (e.g. Figure $3 \mathrm{~b}$ ). In general, Tadao Ando's projects tend to be idealistic, metaphorical, environmentally friendly and full of natural components.
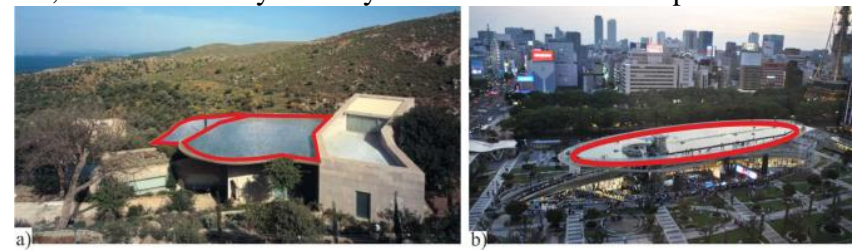

Fig. 4: "Water mirror" technique. a) Residential house, Turkey, Globa Architectural Development, photo by Kvadr.Info; b) Spaceship Aqua, Nagoya, Japan Source: [17]

"Cascade" technique (e.g. Figure 4a) can be used on an interspace level and as part of an upper or a lower basic plane. The name of the technique reflects its nature, water flows from one plane to the other and freely falls downwards. This technique is widely exploited in building of hotels on remote islands, it gives an opportunity to feel as part of the nature. Utopic idea-project Green hiking city (e.g. Figure 6 a) created by Frits Ahlefeldt is a system of separate cascade buildings joined together with passages. The author of the idea wanted to restore the ground lost under the building and to create accessible spaces on building roofs. They include greenery and water components and a mixture of both. Generally, the technique is widely used in such types of buildings as hotels and individual houses. Examples are as follows: Alpin Panorama Hotel Hubertus, Italy, residential house in the United States of America, Hotel Chocolat, France, Marina Bay Sands Resort, Singapore, Hotel One\&Only, Maldives, The Hanging Garden Ubud Pool, Bali, Indonesia, etc.
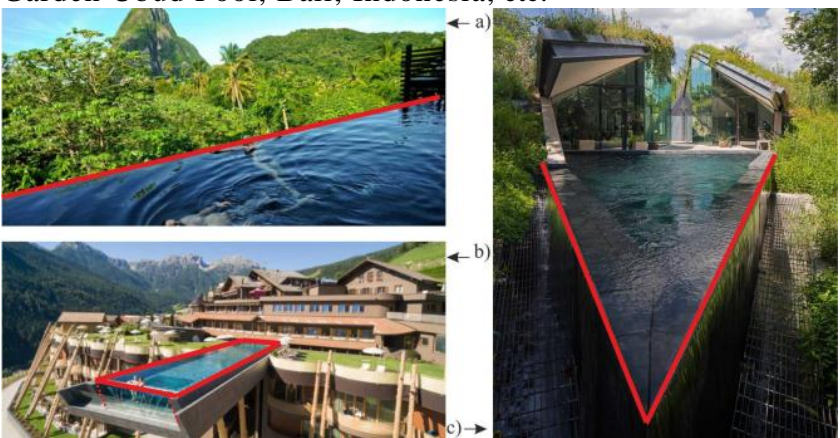

Fig. 4: "Cascade" technique. a) The Hanging Garden Ubud Pool, Bali, Indonesia b) Hotel Hubertus, Italy. Source: [18]; c) Residential house in the United States of America. Source: [19]

Practically all the techniques described by the author of the article referred to the upper basic plane, though there are cases when water is used on the lower basic plane, i.e. the floor. One of the examples is the restaurant in Escudero Villa, San Pablo. In this case the horizontal and the vertical planes are covered with water (e.g. Figure $6 \mathrm{~b}$ ). The imitation of a waterfall is created. It is quite extraordinary that the tables are placed at the end of a water terrace and visitors are in water of about 30-centremetre height. It is more popular to use the "water floor" in the solid physical state. Building from ice dates back to the second half of the first millennium $\mathrm{AD}$ when predecessors of the modern Eskimo learnt to build huts from this material. In modern architecture we can find examples of building ice hotels. The main basic planes of such a building, i.e. the floor, the roof and the walls are made of ice. The number of such hotels increases every year, they are especially popular in ski resorts. The list of ice buildings also grows, there are chapels, churches, ice bars, spa centres, and different museums of ice sculpture.
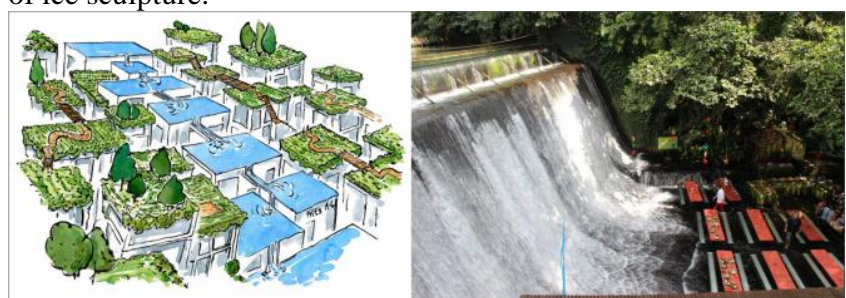

Fig. 6: Green hiking city, Frits Ahlefeldt. Source: [20]; b) restaurant in Escudero Villa, San Pablo, original photo by Tetiana Andronova.

\section{Conclusion}

It has been determined that water is present on different hierarchic levels of perceiving an architectural space. Each level defines the technique of introducing water into its structure. The number of objects in which water as a natural component is used has grown significantly. The character and techniques of introducing the water component in architecture are varied. Taking into account all the above-mentioned facts and in view of the world ecological problems, the use of water in the architecture of buildings is important and timely.

The use of natural components in architectural form making is quite widespread although water as a natural component in the structure of an architectural object is poorly known. The analysis conducted by the author was concentrated on the integration of water elements into the structure of basic horizontal planes of buildings: the floor and the roof; it demonstrated that the replacement of a lower basic plane (floor) with the natural component (on condition that water is in its liquid state) is rare.

The use of water on the upper basic plane (roof) is quite widespread and includes different techniques, such as:

- a water reservoir,

- a swimming pool,

- a water mirror,

- water pools,

- "swimming pool - second light",

- "aquarium",

- swimming pool "bridge",

- "water mirror + entrance",

- "cascade";

these techniques can be combined or be in close proximity to one another. It is necessary to point out that the described natural component can be used separately and in combinations: watersoil, water-vegetation or soil-water-vegetation, which gives an opportunity to create artificial "gardens" in the structure of architectural buildings. The main part of the described techniques does not influence the form making of an architectural object taking into consideration the fact that the basic horizontal plane is only seen by a person from a certain height. However, a number of techniques has particular modifications which give a chance to observe various architectural elements by putting them outside the facade or in the main pedestrian and transport areas of a city. Gradual transition of the landscape component from the horizontal plane to the vertical one produces new techniques. Facades become more flexible due to the use of water in interspaces of an object based on design solutions, configuration of objects, variety 
of materials and the influence on visual perception of large amounts of water. Except aesthetic features the described techniques have great practical value and help to solve the following problems: storage, cleaning and usage of rain water; heat isolation issues; load from wind pressure; improvement of a person's physical and psychological state, etc. The topic is relevant and can be further developed from the perspective of constructive solutions of techniques described by the author.

\section{Acknowledgement}

The author expresses her gratitude for the opportunity to take part in the study of the influence of natural components on the form making of buildings and to express her views on the issue.

\section{References}

[1] Kaluga V. F., V poshukah shlyahu Iz pastki utilltarnogo svItu. IrratsIonalnI chinniki oblashtuvannya spIlnogo svItu yak alternativa zasillyu privatnogo Interesu ta nadumanogo ratsIonalIzmu, Kiyiv, MIlenIum, 2008, $162 \mathrm{~s}$.

[2] Gibson J., The ecological approach to visual perception, Houghton Mifflin company, 1979,443p.

[3] Zaslavskaya A. Yu. Osobennosti organicheskogo podhoda $v$ arhitekture konets XX - nachalo XXI, Nizhniy Novgorod, 2008, 27s.

[4] Chizhmak D. O., Printsipi arhItekturno-planuvalnoi organizatsiii ekologichnih visotnih administrativnih budivel, 2012, 214p.

[5] Gordienko U., Printsipyi formirovaniya prirodointegrirovannoy arhitekturyi, Harkov, 2011, 193 p.

[6] Ching Francas D. K., Architecture. Form, Space \& Order, New York, John Wiley \& Sons, Inc., 1996, 415p.

[7] Luckett K. Green Roof Construction and Maintenance, MC Grow Hill, New York, 2006, 208p.

[8] Aquaria Grande, The Mumbai Apartament Complex With Swimming Pool Balconies [PHOTOS], available online: https://www.huffingtonpost.com/2012/04/04/aquaria-grandemumbai-apartment-complex-swimming-poolbalconies_n_1403741.html, last visit: 09.04.2018.

[9] Arhimir, Basseyn na kazhdom balkone, available online: http://www.archimir.ru/blog/architecture/4646.html, last visit: 15.04.2018.

[10] Kuznetsova Y. The interaction of water and building, «TECHNICAL SCIENCES: MODERN ISSUES AND DEVELOPMENT PROSPECTS», United Kingdom, 2014, pp. 81-87

[11] Basseyn s prozrachnyim dnom na neboskrebe v Hyustone, available online: https://fishki.net/2263520-bassejn-s-prozrachnym-dnom-naneboskrebe-v-hyjustone.html, last visit: 12.04.2018

[12] Ignant. The Wall House By Guedes Cruz Arquitectos, , available online:https://www.ignant.com/2017/10/02/the-wall-house-byguedes-cruz-arquitectos, last visit: 16.04.2018

[13] Moydom, Arhitektura, Sky Habitat v Singapure: novyiy proekt ot znamenitogo Moshe, available online: https://moydom.media/architecture/sky-habitat-v-singapure-novyyproekt-ot-znamenitogo-moshe-safdi-1830, last visit: 20.04 .2018

[14] Top. Tadao Ando Profile, available online: http://www.tadaoando.com/exhibition2017/, last visit: 18.04.2018

[15] Michael Bauer, Peter Mosle, Mchael Schwarz, Green Building Guidebook for Sustainable Architecture, Original German edition published by Callwey verlag, Munich, 2007, 209p.

[16] Home,Cultural experians, Oasis 21, available online: https://japanhighlightstravel.com/en/travel/nagoya/120049/, last visit: 19.04.2018

[17] DRT BRT, Panoramnyiy basseyn so steklyannyim dnom v Dolomitovyih Alpah, available online: https://peritoburrito.com/posts/poolindolomites, last visit: 23.04.2018

[18] Project, Edgeland House / Bercy Chen studio, available online: https://www.archdaily.com/331677/edgeland-house-bercy-chenstudio, last visit: 22.04 .2018

[19] Projects, Hiring and philosophy, available online: https://hiking.org/, last visit: 23.04.2018

[20] Nefedov V.A. Arhitekturno-landshaftnaya rekonstruktsiya kak sredstvo optimizatsii gorodskoy sredyi SPb., 2005, 329 s. RGB OD, 71:05-18/8
[21] Simonds J. O., Landscape Architecture. The shaping of man's natural environment, F. W. Dodge Comporation, New York, NY, 1961, $405 \mathrm{p}$. 